\title{
Chryseobacterium vietnamense sp. nov., isolated from forest soil
}

\author{
Zhikun Li and Honghui Zhu
}

\author{
Correspondence \\ Honghui Zhu \\ zhuhonghui66@yahoo.com.cn
}

\author{
State Key Laboratory of Applied Microbiology (Ministry-Guangdong Province Jointly Breeding \\ Base), South China Guangdong Provincial Microbial Culture Collection and Application Key \\ Laboratory, Guangdong Institute of Microbiology, Guangzhou 510070, PR China
}

A Gram-reaction-negative bacterial strain, designated GIMN1.005 ${ }^{\top}$, was isolated from a forest soil sample in Vietnam. The isolate was yellow-pigmented, strictly aerobic, and unable to grow below $5{ }^{\circ} \mathrm{C}$ or above $37{ }^{\circ} \mathrm{C}$ and in the presence of more than $2.0 \% \mathrm{NaCl}$. Cells were non-motile, non-gliding and non-spore-forming. The yellow pigment was of the flexirubin type, non-diffusible and non-fluorescent. Analysis of 16S rRNA gene sequences showed that strain GIMN1.005 ${ }^{\top}$ occupied a distinct lineage within the genus Chryseobacterium, with sequence similarity values of 98.6, 98.5 and $98.3 \%$ to Chryseobacterium aquifrigidense KCTC $12894^{\top}$, Chryseobacterium jejuense KACC $12501^{\top}$ and Chryseobacterium indologenes GIFU $1347^{\top}$, respectively. The level of DNA-DNA relatedness between strain GIMN1.005 ${ }^{\top}$ and C. jejuense KACC $12501^{\top}$ was $<30 \%$. The DNA G $+\mathrm{C}$ content of strain GIMN1.005 ${ }^{\top}$ was $42.1 \mathrm{~mol} \%$. The predominant cellular fatty acids were iso- $\mathrm{C}_{15: 0}$, iso- $\mathrm{C}_{17: 0} 3-\mathrm{OH}$ and summed feature $3\left(\mathrm{C}_{16: 1} \omega 7 \mathrm{c}\right.$ and/or $\left.\mathrm{C}_{16: 1} \omega 6 c\right)$; menaquinone 6 (MK-6) was the sole respiratory quinone. On the basis of phenotypic properties and phylogenetic distinctiveness, strain GIMN1.005 ${ }^{\top}$ is considered to represent a novel species of the genus Chryseobacterium, for which the name Chryseobacterium vietnamense sp. nov. is proposed. The type strain is GIMN1.005 ${ }^{\top}$ (=CCTCC M $209230^{\top}=N R R L B-59550^{\top}$ ).
The genus Chryseobacterium (Vandamme et al., 1994; Bernardet et al., 2010) is a member of the family Flavobacteriaceae, phylum 'Bacteroidetes', and, at the time of writing, comprised 47 recognized species (http://www. bacterio.cict.fr/c/chryseobacterium.html). Chryseobacterium strains are widely distributed in environments such as soil (Weon et al., 2008; Benmalek et al., 2010), rhizosphere (Young et al., 2005; Park et al., 2006), sludge (Kämpfer et al., 2003; Quan et al., 2007; Pires et al., 2010), fish (de Beer et al., 2006; Ilardi et al., 2009), raw dairy products (Hugo et al., 2003; Hantsis-Zacharov et al., 2008), raw chicken (de Beer et al., 2005), water (Yoon et al., 2007), faeces (Kämpfer et al., 2010) and human clinical specimens (Yassin et al., 2010; Bernardet et al., 2006). Chryseobacterium strains are Gramreaction-negative, non-motile, strictly aerobic, yellow-pigmented rods with menaquinone $6(\mathrm{MK}-6)$ as the major respiratory quinone (Bernardet et al., 2010).

During the course of the characterization of bacterial strains isolated from forest soil at Do Xongpha, Vietnam, a polyphasic approach was used to characterize a Gramreaction-negative, yellow-pigmented, rod-shaped bacterium. Based on the results of this study, we propose to classify this

The GenBank/EMBL/DDBJ accession number for the $16 \mathrm{~S}$ rRNA gene sequence of strain GIMN1.005 ${ }^{\top}$ is $\mathrm{HM} 212415$.

Two supplementary figures are available with the online version of this paper. strain, designated GIMN1.005 ${ }^{\mathrm{T}}$, as a representative of a novel species of the genus Chryseobacterium.

Soil samples were serially diluted in sterile purified water and inoculated on nutrient agar (NA; HuanKai), adjusted to $\mathrm{pH} 7.0$, at $30{ }^{\circ} \mathrm{C}$ for $24 \mathrm{~h}$. Strain GIMN1.005 $5^{\mathrm{T}}$ was isolated on the basis of colony morphology and colour, purified by subculturing and routinely cultured on NA. The culture was suspended in sterile distilled water with $20 \%(\mathrm{w} / \mathrm{v})$ glycerol for storage at $-80{ }^{\circ} \mathrm{C}$.

The 16S rRNA gene of strain GIMN1.005 ${ }^{\mathrm{T}}$ was amplified by PCR with bacterial universal primers 27F and 1527R (Brosius et al., 1981), which were also used for sequencing. The amplified sequenced length was $1390 \mathrm{bp}$. Analysis of the 16S rRNA gene sequence was performed by using the software package MEGA4.0 (Tamura et al., 2007), after multiple alignment of the data by CLUSTAL X (Thompson et al., 1997; Jukes \& Cantor, 1969). Evolutionary distances were used to construct phylogenetic trees via the neighbour-joining (Saitou \& Nei, 1987), minimum-evolution (Rzhetsky \& Nei, 1992) and maximum-parsimony (Swofford, 1993) methods with bootstrap analysis based on 1000 replications. The neighbour-joining tree is shown in Fig. 1. The topology of the trees generated with the three methods was congruent (data not shown). Strain GIMN1.005 ${ }^{\mathrm{T}}$ clearly grouped together with Chryseobacterium aquifrigidense KCTC $12894^{\mathrm{T}}$. Levels of $16 \mathrm{~S}$ rRNA gene sequence similarity were 


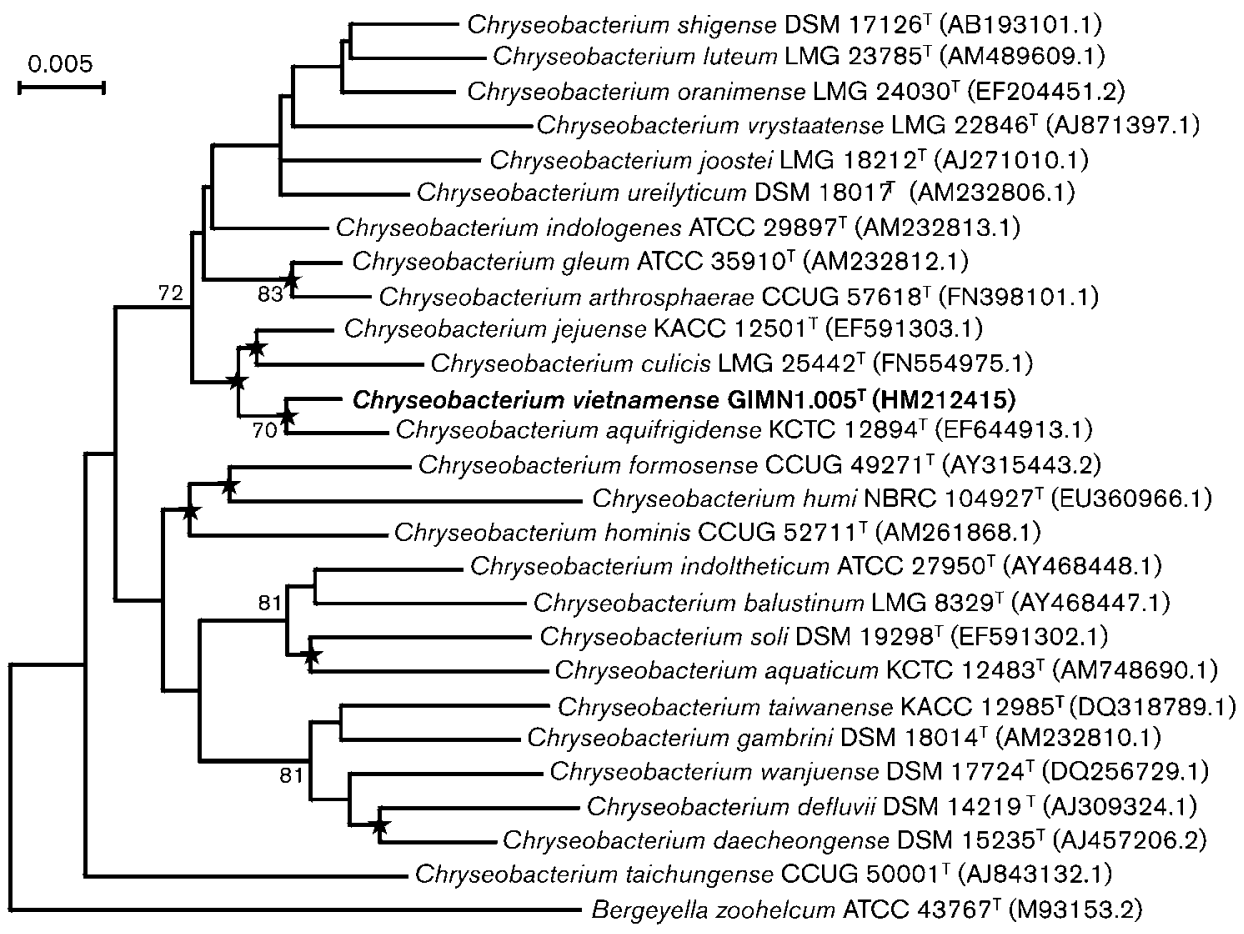

Fig. 1. Neighbour-joining phylogenetic tree based on 16S rRNA gene sequences showing the relationships between strain GIMN1.005 ${ }^{\top}$ and representative members of the genus Chryseobacterium. Bootstrap values (percentages of 1000 resampled datasets) are shown at nodes; only values $\geqslant 70 \%$ are shown. Stars indicate that the corresponding nodes were also recovered in the maximum-parsimony and minimum-evolution trees. The sequence of Bergeyella zoohelcum ATCC $43767^{\top}$ was used as an outgroup. Bar, 0.005 nt substitutions per position.

calculated by pairwise alignment via the EzTaxon database (Chun et al., 2007). On this basis, strain GIMN1.005 ${ }^{\mathrm{T}}$ was related most closely to C. aquifrigidense KCTC $12894^{\mathrm{T}}$, Chryseobacterium jejuense KACC $12501^{\mathrm{T}}$ and Chryseobacterium indologenes GIFU $1347^{\mathrm{T}}$ (98.6, 98.5 and $98.3 \% 16 \mathrm{~S}$ rRNA gene sequence similarities, respectively). Unfortunately, the type strain of $C$. aquifrigidense could not be obtained from culture collections and was therefore not included as a reference strain in this study. For DNA-DNA hybridization experiments, the genomic DNA of strain GIMN1.005 ${ }^{\mathrm{T}}$ was hybridized with that of $C$. jejuense KACC $12501^{\mathrm{T}}$. DNA-DNA hybridization experiments were carried out according to De Ley et al. (1970). The level of DNADNA relatedness between the two strains was $28.6 \pm 0.6 \%$ (mean \pm SD of 5 determinations).

Bacterial growth was tested on MacConkey agar and trypticase soy agar (TSA; HuanKai). Unless otherwise stated, all morphological and tolerance tests were performed on NA. The Gram reaction was tested by using a modification of the method described by Gerhardt et al. (1994), whereas catalase and cytochrome oxidase tests were performed as described by Smibert \& Krieg (1994). Motility was assessed under a Leica DMLB phase-contrast light microscope with Leica Qwin V3 software on cells grown for 1 day in nutrient broth $(\mathrm{NB})$ at $30{ }^{\circ} \mathrm{C}$. For electron microscopy, bacterial cells grown on NA at $30{ }^{\circ} \mathrm{C}$ for $24 \mathrm{~h}$ and suspended in sterile purified water were negatively stained with phosphotungstic acid (3\%, pH 7.0) for 2 min, air-dried and observed with a Hitachi H7650 electron microscope equipped with the appropriate control system software. The phenotypic tests listed below were performed on strain GIMN $1.005^{\mathrm{T}}$ and on its phylogenetic neighbours C. jejuense KACC $12501^{\mathrm{T}}$ and $C$. indologenes GIFU $1347^{\mathrm{T}}$ grown under the same conditions. Acid production from sugars was tested as described by Yamaguchi \& Yokoe (2000). Nitrate reduction was tested in nitrate broth containing $0.2 \% \mathrm{KNO}_{3}$ (Skerman, 1967). Anaerobic growth was investigated by using incubation in an anaerobic pouch (MGC) for 7 days at $30^{\circ} \mathrm{C}$ on NA. The $\mathrm{pH}$ range for growth was determined in buffered trypticase soy broth (TSB) adjusted to $\mathrm{pH} \mathrm{3-10} \mathrm{(at} 1 \mathrm{pH}$ unit intervals). Growth was investigated at 5, 10, 20, 30, 37 and $45{ }^{\circ} \mathrm{C}$ in $\mathrm{NB}$. $\mathrm{NaCl}$ tolerance was investigated on NA containing $2-10 \% \mathrm{NaCl}$ (at $1 \%$ intervals) at $30{ }^{\circ} \mathrm{C}$. The $\mathrm{KOH}$ test was performed according Bernardet et al. (2002) to assess whether the bright yellow pigment produced by strain GIMN1 $1005^{\mathrm{T}}$ was of the flexirubin type. Hydrolysis of casein, gelatin, starch, egg yolk, aesculin and tyrosine was investigated according to the methods described by Smibert \& Krieg (1994). The production of hydrogen sulphide and indole was assessed by using the triple-sugar-iron method and Ehrlich's and Kovács' reagents, respectively. Arginine dihydrolase, lysine decarboxylase, ornithine decarboxylase, 
$\beta$-galactosidase (ONPG) and urease activities were tested as described by Smibert \& Krieg (1994). The ability to oxidize 95 substrates was evaluated by using GN2 MicroPlates (Biolog) incubated for $16-24 \mathrm{~h}$ at $30{ }^{\circ} \mathrm{C}$ according to the manufacturer's instructions.

Cells of strain GIMN1.005 ${ }^{\mathrm{T}}$ were non-motile, non-sporeforming rods surrounded by rather thick appendages of regular length (see Fig. S1 available in IJSEM Online). These appendages have not previously been reported for Chryseobacterium species and were quite different from the fimbriae reported for Chryseobacterium flavum (Zhou et al., 2007). The phenotypic characteristics of strain GIMN $1.005^{\mathrm{T}}$ are given in Table 1 and in the species description below. The following features (taken from Park et al., 2008) distinguish the type strain of $C$. aquifrigidense from strain GIMN1.005 $5^{\mathrm{T}}$ : inability to grow on MacConkey agar and at $5-10{ }^{\circ} \mathrm{C}$, ability to reduce nitrate and significantly lower DNA G + C content.

For fatty acid analysis, strain GIMN1.005 ${ }^{\mathrm{T}}$, C. jejuense KACC $12501^{\mathrm{T}}$ and C. indologenes GIFU $1347^{\mathrm{T}}$ were grown on TSA for $24 \mathrm{~h}$ at $30{ }^{\circ} \mathrm{C}$. Analysis of whole-cell hydrolysates was performed by GLC (Agilent 7890A) according to Kämpfer \& Kroppenstedt (1996) by using the classical method of the Sherlock Microbial Identification System version 6.1 (MIDI)

Table 1. Differential characteristics of strain GIMN1.005 ${ }^{\top}$ and the type strains of closely related Chryseobacterium species

Strains: 1, GIMN1.005 ${ }^{\mathrm{T}} ; 2$, C. indologenes GIFU $1347^{\mathrm{T}} ; 3$, C. jejuense KACC $12501^{\mathrm{T}}$. All data were obtained in this study under the same conditions, except where indicated.

\begin{tabular}{|c|c|c|c|}
\hline Characteristic & 1 & 2 & 3 \\
\hline Growth at $37{ }^{\circ} \mathrm{C}$ & + & + & - \\
\hline $\mathrm{pH}$ range for growth & $6.0-9.0$ & $5.0-8.0$ & $5.0-9.0$ \\
\hline $\begin{array}{l}\text { Growth in the presence of } 3 \% \\
\mathrm{NaCl}\end{array}$ & - & - & + \\
\hline Production of indole & - & + & - \\
\hline Urease activity & - & - & + \\
\hline$\beta$-Galactosidase (ONPG) & + & + & - \\
\hline \multicolumn{4}{|l|}{ Acid production from: } \\
\hline D-Mannitol & + & + & - \\
\hline L-Fucose & + & - & - \\
\hline Trehalose & + & - & - \\
\hline \multicolumn{4}{|l|}{ Oxidation of: } \\
\hline Inositol & + & - & - \\
\hline L-Alanine & + & + & - \\
\hline$N$-Acetyl-D-glucosamine & - & + & - \\
\hline Propionic acid & + & - & - \\
\hline Valeric acid & + & - & - \\
\hline Glycogen & - & + & + \\
\hline L-Serine & + & + & - \\
\hline DNA G $+\mathrm{C}$ content $(\mathrm{mol} \%)^{*}$ & 42.1 & 37.6 & 38.0 \\
\hline
\end{tabular}

${ }^{\star}$ Data for reference strains taken from Weon et al. (2008) and Yabuuchi et al. (1983). and the standard MIS library TSBA6. The major fatty acids of strain GIMN1.005 ${ }^{\mathrm{T}}$ were iso- $\mathrm{C}_{15: 0}$, iso- $\mathrm{C}_{17: 0} 3-\mathrm{OH}$ and summed feature $3\left(\mathrm{C}_{16: 1} \omega 7 c\right.$ and/or $\left.\mathrm{C}_{16: 1} \omega 6 c\right)$. The complete fatty acid profile of strain GIMN $1.005^{\mathrm{T}}$ is shown in Table 2 in comparison with those of the type strains of $C$. jejuense and $C$. indologenes. The overall fatty acid composition of the three strains was very similar, with only minor variations in the respective proportions of some components.

Isoprenoid quinones were isolated from lyophilized cells by using the method of Collins et al. (1977) and were analysed by HPLC (UltiMate 3000; Dionex) as described by Xie \& Yokota (2003). Strain GIMN1.005 ${ }^{\mathrm{T}}$ contained menaquinone 6 (MK-6) as the sole menaquinone, which is in line with all other members of the family Flavobacteriaceae. The genomic DNA of strain GIMN1.005 ${ }^{\mathrm{T}}$ was prepared according to a modification of the procedure described by Wilson (1987). The DNA G + C content of strain GIMN1.005 ${ }^{\mathrm{T}}$, determined by HPLC according to the method of Mesbah et al. (1989), was $42.1 \mathrm{~mol} \%$, a value significantly higher than those reported for related members of the genus Chryseobacterium.

Table 2. Fatty acid contents (\%) of strain GIMN1.005 ${ }^{\top}$ and the type strains of closely related Chryseobacterium species

Strains: 1, GIMN1.005 ${ }^{\mathrm{T}} ; 2$, C. indologenes GIFU $1347^{\mathrm{T}}$; 3, C. jejuense KACC $12501^{\mathrm{T}}$. tr, Trace $(<0.5 \%)$. All data are from this study. Fatty acids amounting to $<1 \%$ in all strains tested are not shown.

\begin{tabular}{|lccc|}
\hline Fatty acid & $\mathbf{1}$ & $\mathbf{2}$ & $\mathbf{3}$ \\
\hline iso- $\mathrm{C}_{13: 0}$ & 0.5 & $\operatorname{tr}$ & 0.7 \\
iso- $\mathrm{C}_{13: 0} 3-\mathrm{OH}$ & 2.9 & $\operatorname{tr}$ & $\operatorname{tr}$ \\
iso- $_{15: 0}$ & 28.5 & 30.1 & 31.3 \\
anteiso- $\mathrm{C}_{15: 0}$ & 0.8 & $\operatorname{tr}$ & $\operatorname{tr}$ \\
anteiso- $\mathrm{C}_{15: 0} \mathrm{~A}$ & 1.0 & $\operatorname{tr}$ & $\operatorname{tr}$ \\
iso- $_{15: 0} 3-\mathrm{OH}$ & 3.7 & 2.9 & 3.1 \\
$\mathrm{C}_{16: 0}$ & 1.8 & 4.5 & 4.2 \\
$\mathrm{C}_{16: 0} 3-\mathrm{OH}$ & $\operatorname{tr}$ & $\operatorname{tr}$ & 1.1 \\
iso- $_{16: 0} 3-\mathrm{OH}$ & 1.0 & 1.0 & $\operatorname{tr}$ \\
iso- $\mathrm{C}_{17: 0}$ & 0.8 & 3.0 & 1.2 \\
$\mathrm{C}_{17: 0} 2-\mathrm{OH}$ & 0.6 & $\operatorname{tr}$ & $\operatorname{tr}$ \\
iso- $_{17: 0} 3-\mathrm{OH}$ & 25.7 & 18.2 & 18.1 \\
iso- $_{17: 1} \omega 9 c$ & 9.4 & 21.7 & 20.8 \\
$\mathrm{C}_{18: 0}$ & 0.5 & $\operatorname{tr}$ & 2.8 \\
$\mathrm{C}_{18: 1} \omega 5 c$ & 2.2 & 0.7 & 0.5 \\
Summed features $^{*}$ & & & \\
1 & 1.6 & $\operatorname{tr}$ & $\operatorname{tr}$ \\
3 & 15.3 & 12.1 & 12.0 \\
5 & 0.8 & $\operatorname{tr}$ & $\operatorname{tr}$ \\
\hline
\end{tabular}

*Summed features represent groups of two or three fatty acids that cannot be separated by GLC with the MIDI system. Summed feature 1 comprised $\mathrm{C}_{16: 1} \omega 7 c$ and/or $\mathrm{C}_{16: 1} \omega 6 c$; summed feature 3 comprised iso- $\mathrm{C}_{15: 0} \mathrm{H}$ and/or $\mathrm{C}_{13: 0}$ 3-OH; summed feature 5 comprised anteiso- $\mathrm{C}_{18: 0}$ and/or $\mathrm{C}_{18: 2} \omega 6,9 c$. 
On the basis of phenotypic data and phylogenetic inference, it is clear that strain GIMN1 $1005^{\mathrm{T}}$ represents a novel species of the genus Chryseobacterium, for which the name Chryseobacterium vietnamense sp. nov. is proposed.

\section{Description of Chryseobacterium vietnamense sp. nov.}

Chryseobacterium vietnamense (vi.et.nam.en'se. N.L. neut. adj. vietnamense of or belonging to Vietnam, the country from where the type strain was isolated).

Cells are Gram-reaction-negative, non-motile, non-sporeforming rods approximately $1.0-2.0 \mu \mathrm{m}$ long and $0.4-0.8 \mu \mathrm{m}$ in diameter surrounded by thick appendages. Strictly aerobic; oxidase- and catalase-positive. Good growth occurs after $24 \mathrm{~h}$ on NA; growth also occurs on MacConkey agar and TSA. Colonies on NA are smooth, bright yellow, circular with entire edges, mucoid, translucent and shiny. Growth occurs at 5-37 ${ }^{\circ} \mathrm{C}$ (optimum, $30{ }^{\circ} \mathrm{C}$ ), at $\mathrm{pH}$ 6-9 (optimum, $\mathrm{pH}$ 7) and in the presence of $0-2.0 \% \mathrm{NaCl}$ (optimum, $0 \%$ ). The non-diffusible and non-fluorescent yellow pigment is of the flexirubin type. Acid is produced from L-fucose, D-glucose, trehalose, D-mannose, D-mannitol and maltose, but not from cellobiose, L-arabinose, D-arabitol, dulcitol, lactose, melibiose, methyl $\alpha$-D-glucoside, raffinose, L-rhamnose, salicin, Dsorbitol, sucrose or D-xylose. Positive for $\beta$-galactosidase activity and for hydrolysis of aesculin, casein, gelatin, starch and tyrosine. Negative for production of indole and hydrogen sulphide and for arginine dihydrolase, lysine decarboxylase, ornithine decarboxylase and urease activities. The following substrates are oxidized in the GN2 MicroPlate: Tween 80, Lfucose, D-fructose, D-galactose, gentiobiose, $\alpha$-D-glucose, myo-inositol, $\alpha$-lactose, lactulose, D-mannose, D-mannitol, maltose, melibiose, D-psicose, raffinose, L-rhamnose, Dsorbitol, sucrose, trehalose, turanose, xylitol, methyl pyruvate, monomethyl succinate, acetic acid, cis-aconitic acid, citric acid, formic acid, D-galactonic acid lactone, D-galacturonic acid, D-glucosaminic acid, D-glucuronic acid, $\alpha$-hydroxybutyric acid, $\beta$-hydroxybutyric acid, $\gamma$-hydroxybutyric acid, $\alpha$ ketobutyric acid, $\alpha$-ketoglutaric acid, $\alpha$-ketovaleric acid, malonic acid, propionic acid, quinic acid, D-saccharic acid, succinic acid, glucuronamide, L-alaninamide, L-alanine, Dalanine, L-alanyl glycine, L-aspartic acid, L-glutamic acid, glycyl glutamic acid, hydroxy-proline, L-histidine, L-leucine, L-ornithine, L-phenylalanine, L-proline, L-serine, L-threonine, $\gamma$-aminobutyric acid, urocanic acid, inosine, thymidine, uridine, 2,3-butanediol, glycerol, glucose 1-phosphate, glucose 6-phosphate and DL- $\alpha$-glycerol. The following substrates are not oxidized: $\alpha$-cyclodextrin, dextrin, glycogen, Tween 40 , $\mathrm{N}$-acetyl-D-galactosamine, $\mathrm{N}$-acetyl-D-glucosamine, adonitol, $\mathrm{L}$-arabinose, D-arabitol, cellobiose, i-erythritol, methyl $\beta$-Dglucoside, D-gluconic acid, p-hydroxyphenylacetic acid, itaconic acid, DL-lactic acid, sebacic acid, bromosuccinic acid, L-pyroglutamic acid, DL-carnitine, phenylethylamine, putrescine and 2-aminoethanol. The major cellular fatty acids $(>15 \%)$ are iso- $\mathrm{C}_{15: 0}$, iso- $\mathrm{C}_{17: 0} 3-\mathrm{OH}$ and summed feature $3\left(\mathrm{C}_{16: 1} \omega 7 c\right.$ and/or $\left.\mathrm{C}_{16: 1} \omega 6 c\right)$. MK-6 is the sole respiratory quinone.
The type strain, GIMN1.005 ${ }^{\mathrm{T}}$ (=CCTCC M $209230^{\mathrm{T}}$ $=$ NRRL B $-59550^{\mathrm{T}}$ ), was isolated from forest soil in Vietnam. The DNA $\mathrm{G}+\mathrm{C}$ content of the type strain is $42.1 \mathrm{~mol} \%$.

\section{Acknowledgements}

This work was supported by the International S\&T Cooperation Program of China (Project no. 2008DFA31560) and Guangdong Ministry of Science and Technology, PR China (Project no. 2009B050300003). We are grateful to Martin Kessel (Center for Cancer Research, Bethesda, MD, USA) for helpful comments on the electron micrographs and Associate Editor Jean-François Bernardet (Institut National de la Recherche Agronomique, Jouy-en-Josas, France) for his constructive suggestions and corrections to the English text.

\section{References}

Benmalek, Y., Cayol, J. L., Bouanane, N. A., Hacene, H., Fauque, G. \& Fardeau, M. L. (2010). Chryseobacterium solincola sp. nov., isolated from soil. Int J Syst Evol Microbiol 60, 1876-1880.

Bernardet, J.-F., Nakagawa, Y., Holmes, B. \& Subcommittee on the taxonomy of Flavobacterium and Cytophaga-like bacteria of the International Committee on Systematics of Prokaryotes (2002). Proposed minimal standards for describing new taxa of the family Flavobacteriaceae and emended description of the family. Int J Syst Evol Microbiol 52, 1049-1070.

Bernardet, J.-F., Bruun, B. \& Hugo, C. J. (2006). The genera Chryseobacterium and Elizabethkingia. In The Prokaryotes, a Handbook on the Biology of Bacteria, 3rd edn, vol. 7, pp. 638-676. Edited by M. Dworkin, S. Falkow, E. Rosenberg, K.-H. Schleifer \& E. Stackebrandt. New York: Springer.

Bernardet, J.-F., Hugo, C. \& Bruun, B. (2010). Genus VII. Chryseobacterium Vandamme et al. 1994. In Bergey's Manual of Systematic Bacteriology, 2nd edn, vol. 4, pp. 180-196. Edited by N. R. Krieg, J. T. Staley, D. R. Brown, B. P. Hedlund, B. J. Paster, N. L. Ward, W. Ludwig \& W. Whitman. New York: Springer.

Brosius, J., Dull, T. J., Sleeter, D. D. \& Noller, H. F. (1981). Gene organization and primary structure of a ribosomal DNA operon from Escherichia coli. J Mol Biol 148, 107-127.

Chun, J., Lee, J. H., Jung, Y., Kim, M., Kim, S., Kim, B. K. \& Lim, Y. W. (2007). EzTaxon: a web-based tool for the identification of prokaryotes based on $16 \mathrm{~S}$ ribosomal RNA gene sequences. Int J Syst Evol Microbiol 57, 2259-2261.

Collins, M. D., Pirouz, T., Goodfellow, M. \& Minnikin, D. E. (1977). Distribution of menaquinones in actinomycetes and corynebacteria. J Gen Microbiol 100, 221-230.

de Beer, H., Hugo, C. J., Jooste, P. J., Willems, A., Vancanneyt, M., Coenye, T. \& Vandamme, P. A. R. (2005). Chryseobacterium vrystaatense sp. nov., isolated from raw chicken in a chickenprocessing plant. Int J Syst Evol Microbiol 55, 2149-2153.

de Beer, H., Hugo, C. J., Jooste, P. J., Vancanneyt, M., Coenye, T. \& Vandamme, P. (2006). Chryseobacterium piscium sp. nov., isolated from fish of the South Atlantic Ocean off South Africa. Int J Syst Evol Microbiol 56, 1317-1322.

De Ley, J., Cattoir, H. \& Reynaerts, A. (1970). The quantitative measurement of DNA hybridization from renaturation rates. Eur $J$ Biochem 12, 133-142.

Gerhardt, P., Murray, R. G. E., Wood, W. A. \& Krieg, N. R. (editors) (1994). Methods for General and Molecular Bacteriology. Washington, DC: American Society for Microbiology. 
Hantsis-Zacharov, E., Senderovich, Y. \& Halpern, M. (2008). Chryseobacterium bovis sp. nov., isolated from raw cow's milk. Int J Syst Evol Microbiol 58, 1024-1028.

Hugo, C. J., Segers, P., Hoste, B., Vancanneyt, M. \& Kersters, K. (2003). Chryseobacterium joostei sp. nov., isolated from the dairy environment. Int J Syst Evol Microbiol 53, 771-777.

Ilardi, P., Fernández, J. \& Avendaño-Herrera, R. (2009). Chryseobacterium piscicola sp. nov., isolated from diseased salmonid fish. Int $J$ Syst Evol Microbiol 59, 3001-3005.

Jukes, T. H. \& Cantor, C. R. (1969). Evolution of protein molecules. In Mammalian Protein Metabolism, vol. 3, pp. 21-132. Edited by H. N. Munro. New York: Academic Press.

Kämpfer, P. \& Kroppenstedt, R. M. (1996). Numerical analysis of fatty acid patterns of coryneform bacteria and related taxa. Can $J$ Microbiol 42, 989-1005.

Kämpfer, P., Dreyer, U., Neef, A., Dott, W. \& Busse, H. J. (2003). Chryseobacterium defluvii sp. nov., isolated from wastewater. Int J Syst Evol Microbiol 53, 93-97.

Kämpfer, P., Arun, A. B., Young, C. C., Chen, W. M., Sridhar, K. R. \& Rekha, P. D. (2010). Chryseobacterium arthrosphaerae sp. nov., isolated from the faeces of the pill millipede Arthrosphaera magna Attems. Int J Syst Evol Microbiol 60, 1765-1769.

Mesbah, M., Premachandran, U. \& Whitman, W. B. (1989). Precise measurement of the $\mathrm{G}+\mathrm{C}$ content of deoxyribonucleic-acid by highperformance liquid-chromatography. Int J Syst Bacteriol 39, 159-167.

Park, M. S., Jung, S. R., Lee, K. H., Lee, M. S., Do, J. O., Kim, S. B. \& Bae, K. S. (2006). Chryseobacterium soldanellicola $\mathrm{sp}$. nov. and Chryseobacterium taeanense sp. nov., isolated from roots of sand-dune plants. Int J Syst Evol Microbiol 56, 433-438.

Park, S. C., Kim, M. S., Baik, K. S., Kim, E. M., Rhee, M. S. \& Seong, C. N. (2008). Chryseobacterium aquifrigidense sp. nov., isolated from a water-cooling system. Int J Syst Evol Microbiol 58, 607-611.

Pires, C., Carvalho, M. F., De Marco, P., Magan, N. \& Castro, P. M. L. (2010). Chryseobacterium palustre sp. nov. and Chryseobacterium humi sp. nov., isolated from industrially contaminated sediments. Int J Syst Evol Microbiol 60, 402-407.

Quan, Z. X., Kim, K. K., Kim, M. K., Jin, L. \& Lee, S. T. (2007), Chryseobacterium caeni sp. nov., isolated from bioreactor sludge. Int $J$ Syst Evol Microbiol 57, 141-145.

Rzhetsky, A. \& Nei, M. (1992). A simple method for estimating and testing minimum-evolution trees. Mol Biol Evol 9, 945-967.

Saitou, N. \& Nei, M. (1987). The neighbor-joining method: a new method for reconstructing phylogenetic trees. Mol Biol Evol 4, 406425.

Skerman, V. B. D. (1967). A Guide to the Identification of the Genera of Bacteria, 2nd edn. Baltimore: Williams \& Wilkins.

Smibert, R. M. \& Krieg, N. R. (1994). Phenotypic characterization. In Methods for General and Molecular Bacteriology, pp. 607-654. Edited by P. Gerhardt, R. G. E. Murray, W. A. Wood \& N. R. Krieg Washington, DC: American Society for Microbiology.

Swofford, D. L. (1993). PAUP: phylogenetic analysis using parsimony, version 3.1.1. Champaign, IL: Illinois Natural History Survey.

Tamura, K., Dudley, J., Nei, M. \& Kumar, S. (2007). MEGA4: molecular evolutionary genetics analysis (MEGA) software version 4.0. Mol Biol Evol 24, 1596-1599.

Thompson, J. D., Gibson, T. J., Plewniak, F., Jeanmougin, F. \& Higgins, D. G. (1997). The CLUSTAL_X windows interface: flexible strategies for multiple sequence alignment aided by quality analysis tools. Nucleic Acids Res 25, 4876-4882.

Vandamme, P., Bernardet, J.-F., Segers, P., Kersters, K. \& Holmes, B. (1994). New perspectives in the classification of the flavobacteria: description of Chryseobacterium gen. nov., Bergeyella gen. nov., and Empedobacter nom. rev. Int J Syst Bacteriol 44, 827-831.

Weon, H. Y., Kim, B. Y., Yoo, S. H., Kwon, S. W., Stackebrandt, E. \& Go, S. J. (2008). Chryseobacterium soli sp. nov. and Chryseobacterium jejuense sp. nov., isolated from soil samples from Jeju, Korea. Int J Syst Evol Microbiol 58, 470-473.

Wilson, K. (1987). Preparation of genomic DNA from bacteria. In Current Protocols in Molecular Biology, pp. 2.4.1-2.4.5. Edited by F. M. Ausubel, R. Brent, R. E. Kingston, D. D. Moore, J. G. Seidman, J. A. Smith \& K. Struhl. New York: Green Publishing \& WileyInterscience.

Xie, C. H. \& Yokota, A. (2003). Phylogenetic analyses of Lampropedia hyalina based on the 16S rRNA gene sequence. J Gen Appl Microbiol 49, 345-349.

Yabuuchi, E., Kaneko, T., Yano, I., Moss, C. W. \& Miyoshi, N. (1983). Sphingobacterium gen. nov., Sphingobacterium spiritivorum comb. nov., Sphingobacterium multivorum comb. nov., Sphingobacterium mizutae sp. nov., and Flavobacterium indologenes sp. nov.: glucosenonfermenting gram-negative rods in CDC groups IIK-2 and Iib. Int $J$ Syst Bacteriol 33, 580-598.

Yamaguchi, S. \& Yokoe, M. (2000). A novel protein-deamidating enzyme from Chryseobacterium proteolyticum sp. nov., a newly isolated bacterium from soil. Appl Environ Microbiol 66, 3337-3343.

Yassin, A. F., Hupfer, H., Siering, C. \& Busse, H. J. (2010). Chryseobacterium treverense sp. nov., isolated from a human clinical source. Int J Syst Evol Microbiol 60, 1993-1998.

Yoon, J. H., Kang, S. J. \& Oh, T. K. (2007). Chryseobacterium daeguense sp. nov., isolated from wastewater of a textile dye works. Int J Syst Evol Microbiol 57, 1355-1359.

Young, C. C., Kämpfer, P. K., Shen, F. T., Lai, W. A. \& Arun, A. B. (2005). Chryseobacterium formosense sp. nov., isolated from the rhizosphere of Lactuca sativa L. (garden lettuce). Int J Syst Evol Microbiol 55, 423-426.

Zhou, Y., Dong, J., Wang, X., Huang, X., Zhang, K. Y., Zhang, Y. Q., Guo, Y. F., Lai, R. \& Li, W. J. (2007). Chryseobacterium flavum sp. nov., isolated from polluted soil. Int J Syst Evol Microbiol 57, 1765-1769. 